\title{
The Tax Effects on C Corporations of Coronavirus-Related Stimulus Acts
}

\author{
Micah Frankel \\ California State University, East Bay \\ John Tan \\ California State University, East Bay
}

This paper discusses the tax effects, with a numerical case example, of the three new refundable payroll credits and the forgiven Small Business Interruption Loans created by the Families First Coronavirus Response Act (FFCRA) (2020) and the Coronavirus Aid, Relief and Economic Security (CARES) Act (2020) respectively. The CARES Act (2020) changed business tax provisions in three main areas: net operating losses, business interest expense deduction, and qualified improvement property. Through three case examples, this paper illustrates numerically how taxpayers can reduce their Federal corporation income tax liabilities by either filing amended returns for past tax years and/or strategically planning to take advantage of the changes in tax rules created by the CARES Act (2020).

Keywords: CARES Act (2020), FFCRA (2020), small business interruption loans

\section{INTRODUCTION}

With the advent of the Coronavirus Disease (COVID-19) in the first half of 2020, three separate coronavirus-related legislative bills were enacted in an effort to help boost the economy. On March 18, 2020, the Families First Coronavirus Response Act (FFCRA) went into effect. Then on March 27, 2020, the largest stimulus package in US history (\$2.2 trillion), the Coronavirus Aid, Relief and Economic Security (CARES) Act, became law (U.S. Department of the Treasury, 2020). Later on June 5, 2020, the Paycheck Protection Program Flexibility Act (PPPFA) went into effect.

FFCRA (2020) provided two new refundable payroll tax credits (i.e. the Paid Sick Leave Credit and the Child Care Leave Credit) to reimburse small and midsize employers with fewer than 500 employees for the cost of providing Coronavirus-related sick leave and childcare leave to their employees. The CARES Act (2020) provides an Employee Retention Credit for 50 percent of qualified wages (including certain health plan costs) paid by qualified employers to retain each employee between March 12, 2020 and December 31, 2020.

The CARES Act (2020) created a Paycheck Protection Program (PPP) to provide loans to small businesses. Through the Small Business Administration (SBA), the PPP provides Small Business Interruption Loans to help small businesses keep workers employed and to partially cover overhead expenses of businesses throughout the COVID-19 pandemic. The PPPFA (2020) stipulates the detailed requirements for a PPP loan to be 100 percent forgiven. 
The CARES Act (2020) also rolled back three areas of the business tax provisions, implemented in the Tax Cuts and Jobs Act (TCJA) (2017), which primarily affected C corporations. First, the CARES Act (2020) now allows net operating losses (NOLs) created in 2018, 2019, and 2020 to be carried back up to five years and no longer limited to 80 percent of taxable income under TCJA (2017). Second, the CARES Act (2020) has increased the limitation on the deduction for business interest under Section 163(j) from 30 percent to 50 percent of adjusted taxable income for 2019 and 2020 tax years. Third, the CARES Act (2020) classifies qualified improvement property (QIP) (certain improvements to the interior of nonresidential real property) placed in service in 2018 retroactively as 15-year property for depreciation purposes.

The U.S. Department of the Treasury (USDT), Labor Department, Internal Revenue Service (IRS), and SBA have been continuously issuing guidelines, notices, and updates to provide more details regarding the implementation of the Paid Sick Leave Credit, Child Care Leave Credit, Employee Retention Credit, and PPP loans (particularly in regard to loan forgiveness eligibility). Thus far, academic discussion is just beginning regarding the effects of the newly created refundable payroll tax credits and 100 percent forgiven PPP loans on Federal corporate income tax liabilities.

The IRS has provided numerical examples to explain the newly created refundable payroll tax credits. The SBA has also provided numerical examples to explain the details of the PPP loans. As of the time of writing this paper, the IRS has yet to provide any numerical examples illustrating the changes in business tax provisions in regard to (1) carryback of NOLs created in 2018, 2019, and 2020, (2) increases in the limitation of Section 163(j) interest expenses deduction, and (3) the classification of QIP as 15-year property for depreciation purposes. This paper fills this void by providing readers with numerical illustrations of how business owners should either amend their past tax returns and/or initiate tax planning to reduce their Federal corporate income tax liabilities in light of the above-mentioned changes in business tax provision.

The first objective of this paper is to highlight the implications of the newly created refundable payroll tax credits and 100 percent forgiven PPP loans. In this regard, key tax rules are reviewed from the business owners' point of view. This paper also provides a case example to illustrate highlighted tax rules.

The second objective of this paper is to provide three different case examples to illustrate each of the changes in the area of NOLs, business interest deductions, and QIP. A C corporation business owner can carry back an NOL created in 2018 (under a 21 percent flat tax regime) to offset taxable income of 2013 (under a progressive 38 percent tax regime). A $\mathrm{C}$ corporation can also deduct business interest expense up to 50 percent of its adjusted taxable income in 2019 and 2020. Since QIP is now classified as 15-year property class for depreciation purposes, a C corporation can first elect Section 179, then further elect Section 168(k) additional first-year depreciation to recover all the cost of QIP acquired and paid after 2017.

Because tax laws apply differently to different legal entities e.g., S Corporations, C Corporations, Partnerships, etc., the term 'taxpayer or eligible business owner' in this paper signifies a C corporation. The property described in this paper is assumed to be 100 percent for business use, acquired, paid, and placed in service in the same tax year. The remainder of this paper is presented as follows: The next section is a literature review. The third section provides a summary of the latest updates of refundable payroll tax credits and the PPP. The fourth section describes Federal corporation income tax effects of the refundable payroll tax credits and 100 percent forgiven PPP loans. The fifth section describes changes to three areas of business tax provisions. The fifth section also provides three real-life cases to illustrate changes to three areas of business tax provisions by the CARES Act (2020). The final section provides a conclusion.

\section{LITERATURE REVIEW}

A wide range of publications exists regarding tax avoidance strategies. This section provides readers with some examples of prior literature on the deductibility of business expenses and tax planning.

Bank (2014) provides a historical perspective on the corporate interest deduction and explains the reason why there is a cap on business interest expense deduction. According to Bank (2014), legislators in 1909 were concerned that corporations would become over-leveraged in an effort to avoid entity-level taxes without a limitation on business interest deductions. 
Changes in tax laws often have implications on society. Hanson (2011) attempts to quantify the effects of interest subsidy through the home mortgage interest deduction. Hanson (2011) finds that in the absence of home mortgage interest deduction, the interest rates on a mortgage loan originated in 2014 would actually decrease by between 3.3 percent and 4.4 percent. Binner and Day (2015) also find that tax policy changes in the deductibility of mortgage interest significantly influence taxpayers' behavior in homeownership.

Hanlon and Heitzman (2010), in their literature review of tax research, discuss four areas of literature: (1) the informational role of income tax expense reported for financial accounting, (2) corporate tax avoidance, (3) corporate decision making, and (4) taxes and asset pricing. In the area of corporate tax avoidance, Wide and Wilson (2018) provide a broad review of corporate tax planning literature of the last decade. Dyreng et al. (2010) find that the level of tax avoidance by a corporation is influenced significantly by the individual executive of that corporation. On the other hand, Khan et al. (2017) suggest that increases in institutional ownership are associated with increases in tax avoidance. Khan et al. (2017) also find that tax shelters are commonly used for tax avoidance. Instead of having tax shelters, which are unaffordable to most taxpayers, small and midsize business owners depend on their accountants for tax advice.

Although most of the literature on tax avoidance or tax planning focuses on public corporations, Decker and Ray (2017) suggest tax strategies to help small and midsize farmers to reduce tax liabilities. In their study, Decker and Ray (2017) first highlight some of the special provisions of the current U.S. tax laws that provide U.S. farmers favorable tax treatment and then suggest thirteen tax strategies for the reduction of a farmer's current or future tax liability.

This paper examines the special tax provisions of the new public laws of 2020 that provide U.S. business owners favorable tax treatment. The focus is on how business owners can legitimately reduce their tax liabilities by taking advantage of the latest changes in the tax law.

\section{REFUNDABLE PAYROLL TAX CREDITS \& PAYCHECK PROTECTION PROGRAM}

\section{Paid Sick Leave Credit and Child Care Leave Credit}

On March 20, 2020, the USDT, IRS, and the U.S. Department of Labor (Labor) issued News Releases IR-2020-57 (IRS, 2020a) to provide small and midsize businesses with detailed guidance on the implementation of the two new refundable payroll tax credits created by the FFCRA (2020).

FFCRA (2020) provides that employees of eligible employers can receive (1) up to 80 hours of paid sick leave at 100 percent of the employee's pay where the employee is unable to work because he or she is going through quarantine, experiencing COVID-19 symptoms, seeking medical treatment; (2) up to 80 hours of paid sick leave at two-thirds of the employee's pay where the employee is unable to work because he or she is caring for an individual with Coronavirus or caring for a child whose school is closed or a child care provider is unavailable for reasons related to COVID-19; (3) up to ten weeks of child care leave equal to two-thirds of the employee's pay where the employee is unable to work because he or she is caring for a child whose school is closed or a child care provider is unavailable for reasons related to COVID-19 (IRS, 2020a).

To reimburse employers for their cost of providing Coronavirus-related sick leave and child care leave to their employees between April 1, 2020 and December 31, 2020, FFCRA (2020) provides two new refundable payroll tax credits: Paid Sick Leave Credit and Child Care Leave Credit. Self-employed individuals have equivalent credits based on similar circumstances.

The Paid Sick Leave Credit (IRS, 2020a) has two parts. For an employee who is unable to work because he or she is going through quarantine, experiencing COVID-19 symptoms, seeking medical treatment, eligible employers can receive a refundable sick leave credit for sick leave at the employee's regular rate of pay, up to $\$ 511$ per day and $\$ 5,110$ in aggregate, for a total of 10 days. For an employee who is unable to work because he or she is caring for an individual with Coronavirus or caring for a child whose school is closed or a child care provider is unavailable for reasons related to COVID-19, eligible employers may

claim a credit for two-thirds of the employee's regular rate of pay, up to $\$ 200$ per day and $\$ 2,000$ in aggregate, for up to 10 days. 
For an employee who is unable to work because he or she is caring for a child whose school is closed or a child care provider is unavailable for reasons related to COVID-19, the Child Care Leave Credit allows eligible employers to claim a credit for two-thirds of the employee's regular rate of pay, which is capped at $\$ 200$ per day and $\$ 10,000$ in aggregate (IRS, 2020a).

In order to promptly pay employers for their cost of providing Coronavirus-related sick leave and childcare leave to their employees, the IRS allows eligible employers to retain an amount of the payroll taxes equal to the amount of qualifying sick and child care leave that they paid for. The payroll taxes that an eligible employer can retain include withheld federal income taxes, the employee share of Social Security and Medicare taxes, and the employer's share of Social Security and Medicare taxes with respect to all employees. If sufficient payroll taxes to retain for the cost of qualified sick and childcare leave paid do not exist, employers can request an accelerated payment from the IRS. IRS Notice 2020-57 provides the following two examples.

If an eligible employer originally needs to deposit $\$ 8,000$ payroll taxes but paid $\$ 5,000$ in sick leave, the employer can retain $\$ 5,000$ and would only be required under FFCRA (2020) to deposit the remaining $\$ 3,000$ on the due date (IRS, 2020a).

If an eligible employer originally needs to deposit $\$ 8,000$ payroll taxes but paid $\$ 10,000$ in sick leave, the employer can retain $\$ 8,000$ and file a request for an accelerated credit for the remaining $\$ 2,000$ (IRS, 2020a).

\section{Employee Retention Credit}

The IRS website has a webpage entitled "Employee Retention Credit" (IRS, 2020b), which provides guidance to the public regarding the Employee Retention Credit. The CARES Act (2020) provides an Employee Retention Credit of 50 percent of qualified wages (including certain health plan costs) paid by qualified employers to each employee between March 12, 2020 and December 31, 2020 due to the COVID19 pandemic.

The IRS defines a qualified employer (IRS, 2020b) as an employer (1) whose business operation (including tax-exempt) were fully or partially suspended during the 2020 calendar year due to COVID-19 or (2) whose gross receipts of a quarter in 2020 declined by more than 50 percent when compared to the same quarter in 2019

For employers with an average exceeding 100 full-time employees in 2019, qualified wages (IRS, $2020 \mathrm{~b}$ ) are defined as wages and certain health care costs up to a total of $\$ 10,000$ per employee that are not providing services but are being paid by the employer during the period of (1) operation suspension or (2) decline in gross receipts. For employers with an average of less than 100 full-time employees in 2019, qualified wages are defined similarly except that the employees can be providing services. The Employee Retention Credit is not available for self-employed individuals based on similar circumstances.

An eligible employer under both the FFCRA (2020) and the CARES Act (2020) can simultaneously receive all the three refundable payroll credits. Therefore, qualified wages under the Employee Retention Credit do not include wages that an employer received a tax credit for (1) the Paid Sick Leave Credit and (2) the ChildCare Leave Credit under the FFCRA (2020). The IRS allows eligible employers to retain an amount of the payroll taxes equal to the amount of qualifying employees' retention wages that they had previously paid.

\section{Paycheck Protection Program (PPP) of the CARES Act (2020)}

The Paycheck Protection Program (PPP) was created by the CARES Act (2020) to provide loans to small businesses in an effort to help them retain their employees and to cover operating expenses (i.e. rent, utilities, interest on existing debt, like a mortgage) of the businesses throughout the period of COVID-19 emergency. Administered through the Small Business Administration (SBA), the PPP created a new loan program (Small Business Interruption Loan) that offers loan forgiveness to companies maintaining a high percentage of their workers on their payroll. The PPPFA (2020) clarified how loans under the PPP of the CARES Act can be forgiven. 
On June 25, 2020, the SBA and the USDT updated the document titled "Paycheck Protection Program Loans Frequently Asked Questions" (SBA, 2020) in an effort to provide businesses with guidance on the implementation of the PPP, established by section 1102 of the CARES Act (2020). Below is a brief summary of the key points of the PPP.

In general, the PPP applies to any business, nonprofit organization, veterans' organization, tribal business, agricultural producer, farmer, and rancher that was in operation on February, 2020 and meet one of the following conditions: (1) has less than 500 employees, (2) has 500 employees or more but meet the standards of the SBA, (3) has less than 500 employees per physical location for all food service and accommodation businesses.

Eligible employers can apply for a Small Business Interruption Loan (SBIL) up to 2.5 times their average monthly payroll. This amount is capped at a maximum of $\$ 10$ million. In general, borrowers can use their aggregate payroll costs (calculated on a gross basis without regard to Federal taxes withheld) either from the previous 12 months or from the 2019 calendar year to determine their number of employees and maximum loan amounts.

For the purpose of PPP loans, payroll costs cover all cash compensation paid to employees (including costs for employee vacation, parental, family, medical, and sick leave) but exclude (1) wages refunded by Paid Sick Leave Credit and Child Care Leave Credit under FFCRA (2020) and (2) each employee with annual compensation of $\$ 100,000$ or above.

An eligible employer who received an SBIL cannot simultaneously receive the Employee Retention Credit under CARES Act (2020). However, an eligible employer who received covered SBIL can also receive the Paid Sick Leave Credit and Child Care Leave Credit under the FFCRA (2020).

In general, PPP loans can be 100 percent forgivable if employers maintain specified employment and wage levels, as measured by the number of full-time equivalent employees and wage levels over a 24-week "covered period" until December 31, 2020. The 24-week period starts on the date the lender disburses the PPP loan to the borrower.

The SBA announced that it will update the above-mentioned document continuously, so readers should always refer back to the SBA website for the latest information. It is beyond the scope of this paper to describe full details of the rules of the PPP. Instead, this paper focuses on the Federal corporate income tax effects of the newly created tax credits and changes to the tax law by both the FFCRA (2020) and the CARES Act (2020).

\section{DISCUSSION OF TAX EFFECTS: TAX CREDITS AND PPP LOANS}

It is prudent for employers to keep up to date with the various corona-related tax credits and deductions when filing for their 2020 Federal corporate income tax returns. For example, on April 30, 2020, the IRS issued Notice 2020-32 (IRS, 2020c), which does not allow for the deduction of an otherwise deductible expense if that expense resulted in the forgiveness of a covered loan that was excluded from gross income pursuant to Section 1106(i) of the CARES Act (2020).

The CARES Act (2020) allows PPP loans that are used to cover certain business expenses to be partially or wholly forgiven. Further, the CARES Act (2020) specifically provides that loans forgiven under the PPP are not subject to income tax. In the Notice 2020-32, the IRS states that business expenses (such as payroll costs or rent) used to determine the forgiveness of a PPP loan are not deductible for tax purposes (IRS, 2020c). The rationale is that no tax deduction is available for business expenses that are paid with taxexempt dollars (i.e. forgiven PPP loan).

Table 1 highlights some of the key taxation rules that affect the 2020 tax return (including gross income and deduction of business expenses) in relation to (1) Paid Sick Leave Credit, (2) Child Care Leave Credit, (3) Employee Retention Credit, and (4) Forgiven PPP loan. Table 1 also shows that when filing their 2020 $\mathrm{C}$ corporation Federal income tax return, eligible employers include both the Pay Sick Leave Credit and the Child Care Leave Credit of FFCRA (2020) as gross income, and also deduct the related payment of qualified leave wages as business expenses simultaneously in the same tax return (IRS, 2020d). 
On their $2020 \mathrm{C}$ corporation Federal income tax return, eligible employers cannot include: (1) the Employer Retention Credit or forgiven PPP loans of the CARES Act (2020) as gross income and (2) related payment of qualified leave wages or payment of wages, rent, utilities, and interests as part of business expenses deduction in the same tax return (IRS, 2020e). Eligible employers who received PPP loans cannot apply for the Employer Retention Credit.

TABLE 1

TAX CREDITS OF FFCRA (2020) AND PPP LOANS OF CARES ACT (2020)

\begin{tabular}{|c|c|c|}
\hline Key Rules & Details of Key Rules & Sources \\
\hline \multicolumn{3}{|l|}{ 1. Paying For } \\
\hline A. Covered PPP loan & $\begin{array}{l}\text { Covered loan pay for (1) payroll costs, }(2) \text { certain } \\
\text { employee benefits relating to healthcare, }(3) \\
\text { interest on mortgage obligations, }(4) \text { rent, } \\
\text { (5) utilities, and (6) interest on any other existing } \\
\text { debt obligations. }\end{array}$ & $\begin{array}{l}\text { IRS, } 2020 \text { c, } \\
\text { p. } 1\end{array}$ \\
\hline B. Pay Sick Leave & Refundable payroll tax credit to pay for employees' & IRS, 2020a \\
\hline Credit & $\begin{array}{l}\text { leave between April } 1,2020 \text { and December } 31 \text {, } \\
2020 \text { : (1) each employee on sick leave for up to } \\
10 \text { days at } \$ 511 \text { per day, }(2) \text { each employee on } \\
\text { leave to care for an individual with COVID- } 19 \text { or } \\
\text { to care for a child up to } 10 \text { days at } \$ 200 \text { per day. }\end{array}$ & \\
\hline $\begin{array}{l}\text { C. Child Care Leave } \\
\text { Credit }\end{array}$ & $\begin{array}{l}\text { Refundable payroll tax credit to pay for each } \\
\text { employee on child care leave, between April } 1 \text {, } \\
2020 \text { and December } 31,2020 \text {, up to } \$ 10,000 \text { in } \\
\text { aggregate at } \$ 200 \text { per day. }\end{array}$ & IRS, 2020a \\
\hline $\begin{array}{l}\text { D. Employee Retention } \\
\text { Credit }\end{array}$ & $\begin{array}{l}\text { Refundable payroll tax credit to pay for each } \\
\text { retained employee up to } 50 \text { percent of qualified } \\
\text { wages between March 12,2020 and December } \\
31,2020 \text {. }\end{array}$ & IRS, $2020 b$ \\
\hline \multicolumn{3}{|l|}{ 2. Taxable Income } \\
\hline A. Forgiven PPP Loans & Not taxable as gross income. & $\begin{array}{l}\text { IRS, } 2020 \mathrm{c} \\
\text { p. } 1\end{array}$ \\
\hline $\begin{array}{l}\text { B. Pay Sick Leave } \\
\text { Credit }\end{array}$ & Includes full amount of the credits in gross income. & $\begin{array}{l}\text { IRS, 2020d, } \\
\text { Question } 49\end{array}$ \\
\hline $\begin{array}{l}\text { C. Child Care Leave } \\
\text { Credit }\end{array}$ & Includes full amount of the credits in gross income. & $\begin{array}{l}\text { IRS, 2020d, } \\
\text { Question } 49\end{array}$ \\
\hline $\begin{array}{l}\text { D. Employee Retention } \\
\text { Credit }\end{array}$ & Not taxable as gross income. & $\begin{array}{l}\text { IRS, 2020e, } \\
\text { Question } 86\end{array}$ \\
\hline \multicolumn{3}{|l|}{ 3. Business Expenses } \\
\hline A. Forgiven PPP Loans & Related business expenses are not deductible. & $\begin{array}{l}\text { IRS, } 2020 \mathrm{c} \\
\text { p. } 1\end{array}$ \\
\hline $\begin{array}{l}\text { B. Pay Sick Leave } \\
\text { Credit }\end{array}$ & Payments of qualified leave wages are deductible. & $\begin{array}{l}\text { IRS, 2020d, } \\
\text { Question 50 }\end{array}$ \\
\hline $\begin{array}{l}\text { C. Child Care Leave } \\
\text { Credit }\end{array}$ & Payments of qualified leave wages are deductible. & $\begin{array}{l}\text { IRS, 2020d, } \\
\text { Question 50 }\end{array}$ \\
\hline $\begin{array}{l}\text { D. Employee Retention } \\
\text { Credit }\end{array}$ & Disallows deduction of wages paid equal to credits. & $\begin{array}{l}\text { IRS 2020e, } \\
\text { Question } 85\end{array}$ \\
\hline
\end{tabular}

Table 1 shows key taxation rules about the Pay Sick Leave Credit and Child Care Leave of FFCRA (2020), and the Employer Retention Credit and PPP Loans of CARES Act (2020). 
This paper creates hypothetical cases (based on actual cases) regarding a business referred to as Cares Corporation (CC) to numerically illustrate the tax effects of the COVID-19-inspired legislation. Table 2 illustrates the first case example of $\mathrm{CC}$ focusing on the tax effects of the Paid Sick Leave Credit, the Child Care Leave Credit, and forgiven PPP loans on CC 2020 C corporation tax return. Note that CC does not have a Credit for a Prior Year Minimum Tax Liability. In addition, because CC operates domestically, it does not have any foreign-derived income (tangible or intangible).

TABLE 2

CARES CORPORATION CASE 1: 2020 C CORPORATION TAX RETURN

\begin{tabular}{ll}
\hline Item & Tax Effects on Cares Corporation 2020 Form 1120 \\
\hline A. Forgiven PPP Loans & $\$ 1,000,000$ not taxable as gross income. \\
$\quad$ Related Expenses & Not deductible as business expenses for using the forgiven \\
& PPP loan proceeds to pay for wages, rents, utilities, interest. \\
B. Paid Sick Leave Credit & $\$ 51,100(\$ 5,110 * 10$ employees $)$ taxable as gross income. \\
$\quad$ Related Expenses & Payments of qualified leave wages are deductible. \\
C. Child Care Leave Credit & $\$ 100,000(\$ 10,000 * 10$ employees $)$ taxable as gross income. \\
$\quad$ Related Expenses & Payments of qualified leave wages are deductible.
\end{tabular}

Table 2 shows the tax effects of refundable payroll credits, PPP loans, and related expenses.

Cares Corporation (CC), which has been in operation since the 1950s, operates retail stores and sells sundry items with approximately one hundred employees. CC satisfies all the conditions required for tax credits or PPP loans under the FFCRA (2020) and CARES Act (2020) respectively. Between March 2020 and June 2020, CC had ten employees on COVID-19 related sick leave and another ten employees on COVID-19 related childcare leave. CC utilizes the maximum allowable amount of $\$ 5,110$ of the Paid Sick Leave Credit for each of the ten employees who applied for ten days of sick leave. CC also utilizes the maximum allowable amount of $\$ 10,000$ in aggregate for each of the ten employees who applied for leave to care for their children.

CC successfully applied and received one million dollars of PPP loans from the SBA to pay for wages, rents, utilities, and business interests. CC maintains specified employment and wage levels over the 24week period that starts on the date when the lender disbursed the PPP loan to CC. Assuming CC successfully applies for loan forgiveness, both the one million dollars forgiven PPP loan and the related one million dollars expenses (wages, rents, utilities, and business interest) will not be included in CC's $2020 \mathrm{C}$ corporation Federal income tax return.

If the PPP loan to $\mathrm{CC}$ is not forgiven, then $\mathrm{CC}$ has either a two-year maturity or five-year maturity depending on whether CC receives an SBA loan number before or after June 5, 2020 (SBA, 2020, question 49). If CC needs to repay the PPP loan, then all necessary expenses that CC paid or incurred while running the retail business during the taxable year are deductible as per Section 162. The next section discusses how the CARES Act (2020) changes the tax law, which affects several tax years' returns.

\section{CARES ACT (2020): BUSINESS TAX PROVISIONS CHANGES}

\section{Net Operating Loss}

Under TCJA (2017), a C corporation carries forward indefinitely its NOL in a tax year ending after 2017 to offset against 80 percent of the taxable income (determined without regard to the NOL deduction) for those future years. Section 172(d) allows a corporation to include the dividends received deduction, but C Corporations cannot deduct net capital losses in the NOL computation. The CARES ACT (2020) provisionally suspends the $80 \%$ taxable income NOL limitation for taxable years beginning before January 1, 2021. The CARES ACT (2020) provides businesses with immediate succor by allowing NOLs created 
in the 2018, 2019, and 2020 tax years to be carried back up to five years and offset 100 percent of the taxable income for those five years.

Under TCJA (2017), effective January 1, 2018, U.S. C corporations are taxed at a flat 21 percent and they are no longer subject to Alternative Minimum Tax. Prior to 2018, the taxable income of a corporation was taxed at a progressive rate up to a maximum of 38 percent. The CARES Act creates incentives for $\mathrm{C}$ Corporations to carry back NOLs created in a tax year with lower tax rates (for example, 2020 taxed at 21 percent) to offset 100 percent of the taxable income in a tax year with a higher tax rate (for example, 2015 taxed at a higher progressive rate of up to 38 percent). In general, $\mathrm{C}$ corporations are required to carry back the NOL to the earliest profitable tax year allowed.

Table 3 illustrates a second case example of Cares Corporation (CC) carrying back an NOL created in 2020 to offset 100 percent of its taxable income in 2015, 2016, and 2017.

TABLE 3

CARES CORPORATION CASE 2: NOL CARRIED BACKWARD

\begin{tabular}{|c|c|c|c|c|}
\hline Item & & $\$$ & & 2020 \\
\hline NOL of 2020 & & & & $(\$ 1,500,000)$ \\
\hline Taxable Income & 2015 & $\$ 500,000$ & Carried Backward $100 \%$ set off & $\$ 500,000$ \\
\hline Taxable Income & 2016 & $\$ 600,000$ & Carried Backward $100 \%$ set off & 600,000 \\
\hline Taxable Income & 2017 & $\$ 700,000$ & Carried Backward $100 \%$ set off & $\$ \quad 400,000$ \\
\hline & & & NOL of 2020 & 0 \\
\hline
\end{tabular}

Table 3 shows that the 2020 carried back NOL of \$1,500,000 is 100 percent offset taxable Income of 2015, 2016, and 2017 respectively.

Assuming Cares Corporation has a $\$ 1,500,000$ NOL in the year 2020, CC can now carry back this one and half a million-dollar NOL to set off 100 percent of the taxable income first in 2015, then in 2016 and the remaining in 2017. Table 3 shows that the carryback of the $\$ 1,500,000 \mathrm{NOL}$ of the year 2020 is 100 percent set off against the taxable income of $\$ 500,000$ in $2015, \$ 600,000$ in 2016 , and $\$ 400,000$ in 2017. CC needs to amend its Federal corporate income tax return for 2015, 2016, and 2017 in order to apply the carried back NOL of 2020 .

\section{Increased Section 163(j) Limitation of Interest Expense Deduction}

For tax years beginning after 2017, all taxpayers are subject to the limitation on the deduction for business interest under Section 163(j) as amended by TCJA (2017). However, Section 163(j), which is business interest deduction limitation, does not apply to small businesses with average gross receipts of \$26 million or less for the prior three-year period beginning in 2019

The amount of business interest that a taxpayer can deduct in a tax year is limited to the sum of (1) the taxpayer's business interest income for the year, (2) 30 percent of the taxpayer's adjusted taxable income (ATI) for the year, and (3) the taxpayer's floor plan financing interest for the year (IRS, 2019). Floor plan financing interest is the interest paid to finance the acquisition of motor vehicles purchased for resale or lease (IRS, 2019).

Adjusted taxable income is taxable income computed without regard to (1) nonbusiness income, gains or losses; (2) any business interest or business interest income; (3) the amount of any NOL deduction; (4) the amount of any deductible qualified business income under Section 199A; and (5) allowable deductions for depreciation, amortization, or depletion. For taxable years beginning on or after January 1, 2022, taxpayers compute ATI with regard to deductions for depreciation, amortization, and depletion or simply Earnings Before Interest, Tax, Depreciation, or Amortization (IRS, 2019).

The CARES Act (2020) has also temporarily increased the ability of businesses to deduct interest expense under Section 163(j) by raising deductible interest from 30 percent to 50 percent of adjusted taxable 
income in taxable years 2019 or 2020 . The above-mentioned increase from 30 percent to 50 percent does not apply to a partnership during the 2019 taxable year. Due to the COVID-19 pandemic and resulting shelter-in-place policy, business owners most probably will have a smaller amount of taxable income in 2020. The CARES Act (2020) therefore allows taxpayers to use their 2019 adjusted taxable income when calculating their 2020 interest expense limitation.

Table 4 illustrates the third case example of Cares Corporation focusing on the deduction limitation of business interest under Section 163(j) for 2019 tax year.

TABLE 4

CARES CORPORATION CASE 3: BUSINESS INTEREST DEDUCTION 2019

\begin{tabular}{|c|c|c|c|}
\hline Description & Amount & ATI & Limitation \\
\hline Business Income & $\$ 400$ & & \\
\hline Business Interest Income & $\$ 40$ & & \\
\hline Cost of Goods Sold & $(\$ 160)$ & & \\
\hline Business Interest Expense & $(\$ 100)$ & & \\
\hline Depreciation & $(\$ 60)$ & & \\
\hline Taxable Income Before Section 163(j) Limitation & $\$ \$ 120$ & $\$ 120$ & \\
\hline Minus: Interest Income $\$ 40$ & & $(\$ 40)$ & \\
\hline Add back: Net Interest Expense $(\$ 100)$ & & $\$ 100$ & \\
\hline Add back: Depreciation $(\$ 60)$ & & $\$ 60$ & \\
\hline Adjusted Taxable Income (ATI) & & $\$ 240$ & \\
\hline \multicolumn{4}{|l|}{ Limitation on Business Interest Deduction } \\
\hline \multicolumn{4}{|l|}{ Sum of Following: } \\
\hline $201950 \%$ of ATI $(\$ 240 * 50 \%)$ & & & $\$ 120$ \\
\hline Business Interest Income & & & $\$ 40$ \\
\hline Floor Plan Financing Interest & & & $\$ 0$ \\
\hline 2019 Maximum Amount Business Interest Deduction & & & $\overline{\$ 160}$ \\
\hline
\end{tabular}

Table 4 shows that Cares Corporation is subject to the Section 163(j) limitation on business Interest deduction of $\$ 160$. During the 2019 tax year, CC has $\$ 100$ of business interest expense.

Assume that during $2019 \mathrm{CC}$ has a business interest income of $\$ 40$ and business interest expense of $\$ 100$ (with no floor plan financing interest). Table 4 shows that CC has an ATI of $\$ 240$ in 2019 . Under the CARES ACT, CC can input 50 percent of the ATI to calculate its 2019 limitation on the deduction for business interest under Section 163(j). Table 4 shows that the maximum amount of business interest expense that CC can deduct in 2019 is $\$ 160$.

\section{Reclassification of Qualified Improvement Property}

TCJA (2017) increased the amount of immediate expenses under Section 179 to one million dollars and increased the phase-out threshold to two and a half million dollars.

TCJA (2017) also amended Section $168(\mathrm{k})$ to allow a 100 percent additional first-year depreciation deduction for qualified property acquired and placed in service after September 27, 2017. But the percentage of Section 168(k) additional first-year depreciation deduction will begin to decrease, 20 percent per year incrementally, from 100 percent in 2022 to zero percent in 2027 and thereafter (USDT, 2019).

TCJA (2017) disallowed QIP to be eligible for Section 168(k) additional first-year depreciation (USDT, 2019). But Section 179 allows QIP to be immediately expensed. In general, QIP includes any improvement to an interior portion of a building, which is a nonresidential real property if such improvement is placed in service after the date such a building was first placed in service. Note that qualified improvement does not 
include (1) enlargement of the building, (2) elevators, (3) escalators, nor (4) cost of improvement of the internal structural framework of a building.

The CARES Act (2020) classifies QIP as 15-year property for depreciation purposes and retroactively applies the changes to property placed in service in 2018. Section 168(k) only allowed MACRS property that had a recovery period of 20 years or less (USDT, 2019). With a 15-year property classification, QIP now qualifies for Section 168(k) additional first-year depreciation deduction. In fact, taxpayers can even retroactively elect additional first-year depreciation, under Section 168, for QIP acquired and paid for in 2018 by filing an amended return.

Table 5 illustrates the fourth and final case example of Cares Corporation applying Section 179 immediate expense and Section 168(k) additional first-year depreciation to recover the total cost of QIPs paid for in 2019.

TABLE 5

CARES CORPORATION CASE 4: QUALIFIED IMPROVEMENT PROPERTY

\begin{tabular}{ll}
\hline Description & Amount \\
\hline Qualified Improvement Property (QIP) 2019 & $\$ 1,550,000$ \\
Elect Section 179 Immediate Expense & $\$ 1,020,000$ \\
Elect Section 168(k) Additional First-Year Depreciation & $\$ 530,000$ \\
& $\$ \$$ \\
Total Cost Recovery & $\$ 1,550,000$ \\
\end{tabular}

Table 5 shows that Cares Corporation recovers \$1,550,000 cost of qualified improvement property in 2019 by electing both Section 179 and Section $168(\mathrm{k})$.

For the 2019 tax year, the maximum amount of immediate expense and the threshold under Section 179 is $\$ 1,020,000$ and $\$ 2,550,000$ respectively. Assuming CC acquired and paid for $\$ 1,550,000$ of QIP in 2019, $\mathrm{CC}$ first elects Section 179 to immediately expense $\$ 1,020,000$ and subsequently elects Section $168(\mathrm{k})$ to recover the remaining $\$ 530,000$. In total, $\mathrm{CC}$ can fully recover the total amount of $\$ 1,550,000$ of QIP in 2019 because of the new changes in business tax provisions created by the CARES Act (2020).

\section{CONCLUSIONS}

In response to the economic crisis triggered by COVID-19, three separate economic stimulus packages were signed into law: (1) the Families First Coronavirus Response Act (FFCRA), (2) the Coronavirus Aid, Relief and Economic Security (CARES), and (3) the Paycheck Protection Program Flexibility Act (PPPFA). Each of these three laws has significant Federal tax implications for $\mathrm{C}$ corporations.

This paper highlights the latest key points of the three new payroll refundable credits (1) Paid Sick Leave Credit, (2) Child Care Leave Credit, and (3) Employee Retention Credit created by the FFCRA (2020) and the CARES Act (2020) respectively. Further, this paper also summarizes the latest updates on the SBIL of the PPP created by the CARES Act (2020). Readers should always refer to official sources for developing updates.

The IRS has released ongoing guidance and frequently asked questions in regard to the tax rules for the Paid Sick Leave Credit, Child Care Leave Credit, Employee Retention Credit, and the forgiven PPP Loans. This paper contributes to the literature by creating a case example to numerically illustrate the abovementioned key areas that readers should pay attention to when filing their $2019 \mathrm{C}$ Corporation tax return.

The CARES Act (2020) has changed the business tax provisions in three main areas: (1) NOLs, (2) business interest expense, and (3) qualified improvement property. This paper creates three separate case examples to numerically illustrate how these new provisions will benefit taxpayers by either filing amended returns and/or strategically planning to reduce future taxes. 
The authors acknowledge several limitations of this paper. For example, this paper's case examples are not applicable to all taxpayers as each taxpayer's situation is unique.

Many opportunities exist for tax research of the FFCRA (2020), CARES Act (2020), and PPPFA (2020). The authors plan to publish additional manuscripts in the future about the effects of the new public laws on business taxation once more data become available.

\section{REFERENCES}

Bank, S.A. (2014). Historical Perspective on the Corporate Interest Deduction. Chapman Law Review, 18, 29-48.

Binner, A., \& Day, B. (2015). Exploring Mortgage Interest Deduction Reforms: An Equilibrium Sorting Model with Endogenous Tenure Choice. Journal of Public Economics, 122, 40-54.

Coronavirus Aid, Relief, and Economic Security Act. (2020, March 27). H.R. 748; Became Public Law No: 116-136. Retrieved from https://www.congress.gov/bill/116th-congress/house-bill/748

Decker, J., \& Ray, R. (2017). Tax Strategies for U.S. Farmers: Tax Reduction and Average Risk. Accounting and Taxation, 9(1), 49-62.

Dyreng, S., Hanlon, M., \& Maydew, E. (2010). The Effects of Executives on Corporate Tax Avoidance. The Accounting Review, 85(4), 1163-1189.

Families First Coronavirus Response Act. (2020, March 18). H.R. 6201; Became Public Law No: 116127. Retrieved from https://www.congress.gov/bill/116th-congress/house-bill/6201

Hanson, A. (2011). The Incidence of the Mortgage Interest Deduction: Evidence from the Market for Home Purchase Loans. Public Finance Review, 40(3), 339-359.

Hanlon, M., \& Heitzman, S. (2010). A Review of Tax Research. Journal of Accounting and Economics, $50,127-178$.

Internal Revenue Service (IRS). (2019). Basic questions and answers about the limitation on the deduction for business interest expense. Retrieved from https://www.irs.gov/newsroom/basicquestions-and-answers-about-the-limitation-on-the-deduction-for-business-interest-expense

Internal Revenue Service (IRS). (2020a). News Releases IR-2020-57. Treasury, Internal Revenue Service, and Labor announce plans to implement Coronavirus-related paid leave for workers and tax credits for small and midsize businesses to swiftly recover the cost of providing Coronavirusrelated leave. Retrieved from https://www.irs.gov/newsroom/treasury-irs-and-labor-announceplan-to-implement-coronavirus-related-paid-leave-for-workers-and-tax-credits-for-small-andmidsize-businesses-to-swiftly-recover-the-cost-of-providing-coronavirus

Internal Revenue Service (IRS). (2020b). Employee Retention Credit. Retrieved from https://www.irs.gov/coronavirus/employee-retention-credit

Internal Revenue Service (IRS). (2020c). Notice 2020-32. Deductibility of certain expenses relating to the Paycheck Protection Program. Retrieved from https://www.irs.gov/pub/irs-drop/n-20-32.pdf

Internal Revenue Service (IRS). (2020d). COVID-19-Related Tax Credits: Special Issues for Employers FAQs: Taxation and Deductibility of Tax Credits. Retrieved from https://www.irs.gov/newsroom/covid-19-related-tax-credits-special-issues-for-employersfaqs\#special_issues_taxation

Internal Revenue Service (IRS). (2020e). COVID-19-Related Employee Retention Credits: Special Issues for Employers FAQs: Income and Deduction. Retrieved from https://www.irs.gov/newsroom/covid-19-related-employee-retention-credits-special-issues-foremployers-faqs\#income-and-deduction

Khan, M., Srinivasan, S., \& Tan, L. (2017). Institutional Ownership and Corporate Tax Avoidance: New Evidence. The Accounting Review, 92(2), 101-122.

Paycheck Protection Program Flexibility Act. (2020, June 5). H.R. 7010, Became Public Law No: 116142. Retrieved from https://www.congress.gov/bill/116th-congress/housebill/7010/text?q=\%7B $\% 22$ search $\% 22 \% 3 \mathrm{~A} \% 5 \mathrm{~B} \% 22$ Paycheck+Protection+Program+Flexibility+ Act $\% 22 \% 5 \mathrm{D} \% 7 \mathrm{D} \& \mathrm{r}=2 \& \mathrm{~s}=2$ 
Small Business Administration (SBA). (2020). FAQ for Lenders and Borrowers. Retrieved from https://www.sba.gov/document/support-faq-lenders-borrowers

Tax Cuts and Jobs Act. (2017, December 22). H.R. 1; Became Public Law No: 115-97. Retrieved from https://www.congress.gov/bill/115th-congress/house-bill/1/text/eh

26 U.S.C. $\$ 162$

26 U.S.C. $\$ 163(j)$

26 U.S.C. $\$ 168(\mathrm{k})$

26 U.S.C. $\$ 172(d)$

26 U.S.C. $\$ 179$

U.S. Department of the Treasury (USDT). (2019). Additional First-Year Depreciation Deduction (84 FR 50108). Retrieved from https://www.federalregister.gov/documents/2019/09/24/201920036/additional-first-yeardepreciation-deduction

U.S. Department of the Treasury (USDT). (2020). The CARES Act Works for All Americans. Retrieved from https://home.treasury.gov/policy-issues/cares

Wilde, J.H., \& Wilson, R.J. (2018). Perspectives on Corporate Tax Planning: Observations from the Past Decade. The Journal of the American Taxation Association, 40(2), 63-68. 